\title{
Pengaruh Word of Mouth Dan Citra Merek Terhadap Loyalitas Pelanggan Smartphone Oppo Dimediasi Kepercayaan Merek
}

\author{
(The Influence of Word of Mouth and Brand Image on Oppo \\ Smartphone Customer Loyalty is Mediated Brand Trust)
}

Oleh:

Ony Khoirul Huda'), Arief Teguh Nugroho')

PT. Kyokuni High Precision Automotive Indonesia'), Universitas Pelita Bangsa2) Ony.choirul.huda@gmail.com ${ }^{1}$, ariefteguhnugroho@gmail.com²)

\begin{abstract}
ABSTRAK
Tujuan penelitian ini adalah untuk mengetahui pengaruh Word of Mouth dan citra merek terhadap loyalitas pelanggan smarthphone Oppo di Karawang melaui kepercayaan merek sebaga medisi. Populasi penelitian ini adalah pelanggan smarthphone Oppo di Karawang dan sampel yang diambil sebesar 102 orang. Metode analisis data penelitian ini adalah analisis jalur yang sebelumnya diuji dengan uji instrumen dan uji asumsi klasik. Hasil pengujian menunjukkan bahwa Word of Mouth dan citra merek berpengaruh terhadap loyalitas pelanggan smarthphone Oppo di Karawang baik secara langsung maupun tidak langsung.
\end{abstract}

Kata kunci:

Word of Mouth, Citra Merek, Kepercayaan Merek, Loyalitas Pelanggan.

\begin{abstract}
The purpose of this study was to determine the effect of Word of Mouth and brand image on customer loyalty of Oppo smartphones in Karawang through brand trust as meditation. The population of this research is the Oppo smartphone customers in Karawang and the sample taken is 102 people. The data analysis method of this research is path analysis which was previously tested by instrument test and classical assumption test. The test results show that Word of Mouth and brand image affect customer loyalty of Oppo smartphones in Karawang, either directly or indirectly.
\end{abstract}

Keywords:

Word of Mouth, Brand Image, Brand Trust, Customer Loyalty 


\section{PENDAHULUAN}

Semakin terbukanya arus informasi dan semakin berkembangnya tingkat pendapatan dan daya beli, maka pola konsumsi para konsumen pun cenderung berubah. Paling tidak saat ini konsumen lebih cenderung realistis dan rasional sebelum memutuskan untuk mengkonsumsi sesuatu, misalnya produk smartphone.

Penjualan Oppo akhir tahun 2019 mengalami penurunan dengan mulai hilangnya pangsa pasar di beberapa negara khususnya di Indonesia. Data IDC menunjukkan pangsa pasar Oppo pada tahun 2018 kuartal 3 mencapai 20.5\% berbeda dengan tahun 2019 kuartal 3 mengalami penurunan menjadi $16.6 \%$. Data penjualan pada tahun 2018 kuartal ketiga Oppo mampu menjual 21 juta unit, sedangkan pada tahun 2019 kuartal ketiga hanya mampu menjual 16.4 juta unit. Secara keseluruhan Oppo pada tahun 2019 mengalami penurunan sebesar $21.7 \%$.

Fenomena penurunan penjualan smartphone Oppo mengindikasikan terdapat permasalahan loyalitas pelanggan Smartphone Oppo. Permasalahan loyalitas menjadi begitu penting karena terjadi di berbagai organisasi dan ditelaah pada berbagai penelitian (Agustina, Fauzi dan Nuralam, 2018; Yusfita dan Yulianto, 2018; Tamon, Mandey dan Wenas, 2019).

Loyalitas pelanggan akan terbentuk dari banyak faktor. Pelanggan yang loyal terhadap merek atau produk tertentu muncul setelah mereka merasa percaya terhadap produk atau merek tersebut (Putra, 2018). Kesetiaan konsumen merupakan manifestasi dan kelanjutan dari kepercayaan dalam menggunakan produk maupun jasa pelayanan yang diberikan oleh pihak perusahaan, serta untuk tetap menjadi konsumen dari perusahaan tersebut. Kesetiaan adalah bukti konsumen yang selalu menjadi konsumen, yang memiliki kekuatan sikap yang positif atas sebuah produk. Kesetiaan konsumen terhadap suatu barang atau jasa dengan merek tertentu berkemungkinan tergantung pada beberapa faktor diantaranya Strategi Promosi, Citra Merek (Tamon, Mandey dan Wenas, 2019; Kualitas Produk, Kualitas Layanan (Choiriah dan Liana, 2019); Brand Image dan Word of Mouth (Oliviana, Mananeke dan Mintardjo, 2017); Experiental Marketing dan Word of Mouth (Yusfita dan Yulianto, 2018).

Informasi positif yang disampaikan orang lain (Word of Mouth) akan membuat konsumen semakin yakin untuk tetap menggunakannya sehingga word of mouth berpengaruh terhadap loyalitas pelanggan (Hatta dan Setiarini, 2018; Yusfita dan Yulianto, 2018). Disisi lain, rekomendasi mulut ke mulut (Word of Mouth) penting untuk membangun kepercayaan merek (Hasan, 2013: 93). Word of Mouth merupakan sarana yang kuat untuk membangun kepercayaan merek (Lock, 2016) meskipun ada temuan bahwa Word of Mouth tidak berpengaruh terhadap kepercayaan merek (Utami, 2019). Karena kepercayaan merek memberikan pengaruh terhadap Loyalitas (Agustina, Fauzi dan Nuralam, 2018; Putra, 2018; Husain dan Hartati M, 2017) maka Word of Mouth berpengaruh terhadap kepercayaan merek dan berdampak pada loyalitas pelanggan (Oktiani dan Khadafi, 2018).

Tidak kalah penting, citra merek Citra merek (brand image) merupakan aspek yang sangat penting dari merek dan dapat didasarkan kepada kenyataan atau fiksi tergantung bagaimana konsumen mempersepsikanya (Richard, 2016). Konsumen akan mulai menciptakan rasa percaya pada suatu produk ketika konsumen mencoba produk tersebut untuk 
pertama kali (Shimp, 2014: 167). Rasa percaya ini merupakan modal awal dari penciptaan kesadaran merek selanjutnya. Kepercayaan akan mulai terlihat ketika konsumen menunjukkan ungkapan positif setelah mencoba produk tersebut. Kepercayaan dan sikap secara umum saling menguatkan, apabila produk sesuai dengan harapan konsumen maka sikap konsumen terhadap merek tersebut akan positif. Namun sebaliknya, sikap konsumen akan menjadi negatif terhadap suatu merek apabila produknya tidak memenuhi harapan konsumen saat pembelian uji coba. Jika kepercayaan dan sikap positif telah terbentuk dari pengalaman pertama konsumen mencoba maka penting bagi perusahaan untuk menguatkan kepercayaan dan sikap yang telah didapatkan tersebut. Meskipun ada temuan yang menyatakan bahwa citra merek tidak berpengaruh terhadap loyalitas pelanggan (Andjarwati dan Chusniartiningsih, 2019). Karena kepercayaan merek memberikan pengaruh terhadap Loyalitas (Agustina, Fauzi dan Nuralam, 2018; Putra, 2018; Husain dan Hartati M, 2017) maka terdapat pengaruh citra merek terhadap loyalitas pelanggan dimediasi oeh kepercayaan merek (Mabkhot, 2017).

\section{METODE PENELITIAN}

Penelitian dilakukan dengan menyebar kuesioner kepada 102 responden penelitian yaitu pengguna smartphone Oppo di Karawang yang disebar di social media dalam bentuk google doc form. Pengambilan sampel sebagai responden dilakukan dengan metode snow-ball sampling (Mulyanto dan Wulandari, 2010) dimana pengambilan sampel dilakukan secara berantai dengan mengontak satu atau beberapa responden potensial yakni pengguna Smartphone Oppo dilanjutkan ke responden lain yang direkomondasikan.

Metode explanatory research digunakan untuk mengetahui dan menguji hubungan antara 2 variabel atau lebih. Analisis yang akan digunakan dalam penelitian ini adalah analisis jalur atau path analysis. Alasan analisis ini digunakan adalah untuk mengetahui hubungan sebab akibat dan menguji hipotesis yang diajukan dalam penelitian yang dilakukan.

Path analysis digunakan untuk melakukan perkiraan pengaruh antar variabel serta posisi dari setiap variabel dalam jalur yang benar secara langsung maupun tidak langsung. Hubungan keterkaitan model bisa dilihat dari nilai koefisien beta $(\beta)$.

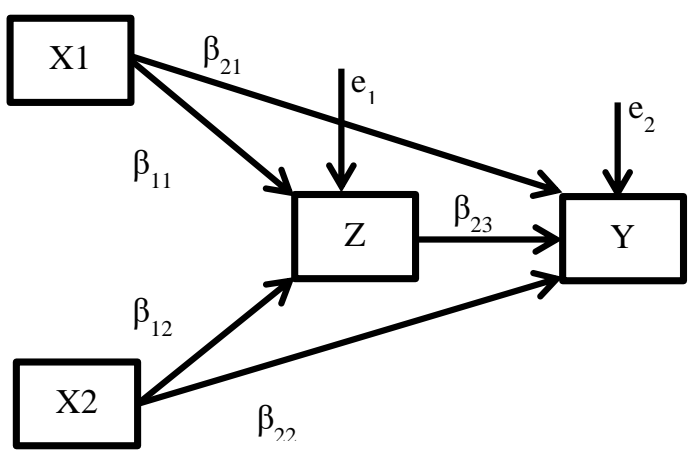

Gambar 1. Desain Penelitian

Gambar 1 memperlihatkan desain penelitian. Y adalah Loyalitas Pelanggan, Z adalah Kepercayaan Merek, X1 adalah Word of Mouth, X2 adalah Citra Merek, e adalah Error Term. Model 1 terdiri dari koefisien WOM $(\beta 11)$ dan Citra Merek $(\beta 12)$ terhadap kepercayaan. Model 2 terdiri dari koefisien WOM ( $\beta 21)$; Citra Merek ( $\beta 22)$ dan Kepercayaan ( $\beta 23)$ terhadap loyalitas. Persamaan model 1 dan model 2 adalah sebagai berikut:

$Z=\beta 1 X 1 Z+\beta 2 X 2 Z+$ e1 $\ldots \ldots \ldots \ldots \ldots \ldots . .1)$

$Y=\beta 1 X 1 Y+\beta 2 X 2 Y+\beta 3 Z Y+e 2 \ldots \ldots \ldots \ldots .2)$ 
Tabel 2. Operasionalisasi Variabel

\begin{tabular}{|c|c|c|}
\hline No. & Variabel & Indikator \\
\hline 1 & $\begin{array}{l}\text { Loyalitas Pelanggan adalah komitmen yang } \\
\text { dipegang secara mendalam untuk membeli } \\
\text { atau mendukung kembali sebuah produk } \\
\text { atau jasa yang disukai di masa depan meski } \\
\text { pengaruh situasi dan usaha pemasaran } \\
\text { berpotensi menyebabkan pelanggan beralih } \\
\text { (Eka Ni'matul Choiriah, 2019) }\end{array}$ & $\begin{array}{ll}\text { 1. } & \text { Repeat Purchase } \\
\text { 2. } & \text { Retention } \\
\text { 3. } & \text { Referrals }\end{array}$ \\
\hline 2 & $\begin{array}{l}\text { Kepercayaaan merek adalah terjadinya } \\
\text { rasa percaya yang dirasakan oleh } \\
\text { konsumen terhadap pengalaman merek. } \\
\text { (Fandy Tjiptono, 2011:95) }\end{array}$ & $\begin{array}{ll}\text { 1. } & \text { Integritas (Integrity) } \\
\text { 2. } & \text { Dapat diandalkan } \\
\text { 3. } & \text { Tidak mengecewakan }\end{array}$ \\
\hline 3 & $\begin{array}{l}\text { Worth of Mouth yaitu proses komunikasi } \\
\text { secara individu maupun kelompok yang } \\
\text { berpa pemberian rekomendasi baik } \\
\text { terhadap suatu produk atau jasa dengan } \\
\text { tujuan untuk memberikan informasi } \\
\text { secara personal. } \\
\text { (Hasibuan, 2008) }\end{array}$ & $\begin{array}{ll}\text { 1. } & \text { Membicarakan } \\
\text { 2. } & \text { Merekomendasikan } \\
\text { 3. } & \text { Mendorong }\end{array}$ \\
\hline 4 & $\begin{array}{l}\text { Citra Merek merupakan segala hal yang } \\
\text { berkaitan dengan merek yang ada di dalam } \\
\text { presepsi para konsumen } \\
\text { (Husni Indrawati ,2019) }\end{array}$ & $\begin{array}{ll}\text { 1. } & \text { Kesan baik } \\
\text { 2. } & \text { Menarik perhatian } \\
\text { 3. } & \text { Memiliki keunikan }\end{array}$ \\
\hline
\end{tabular}

Pendekatan kuantitatif digunakan dalam penelitian ini yaitu pendekatan dengan model inferensial menggunakan analisis regresi linier ganda. Analisis dilakukan melalui tahapan uji instrumen, uji persyaratan analisis, uji model dan uji hipotesis sebagaimana kriteria analisis regresi linier ganda

Uji instrumen melalui uji validitas dan uji reliabilitas. Uji validitas menggunakan nilai corected item correlation sedangkan uji reliabilitas menggunakan Cronbach Alpha. Uji persyaratan analisis yang digunakan yaitu uji asumsi klasik yang terdiri dari normalitas, multikolinieritas, autokorelasi dan heteroskedastisitas. Uji normalitas dilakukan secara grafis (histogram), uji multikolinieritas menggunakan VIF, autokorelasi menggunakan nilai durbin watson, dan heteroskedastisitas secara grafis dengan scatter plot.

Uji model digunakan untuk memastikan kelayakan model. Kelayakan model dilihat dari nilai adjusted $\mathrm{R}$ Square sedangkan pengujiannya dengan uji F. Uji hipotesis menggunakan nilai koefisien regresi untuk menentukan arah pengaruh sedangkan pengujian dilakukan dengan uji-t.

Analisis dilakukan dua kali karena dalam model penelitian ini menggunakan analisis jalur. Seluruh tahapan dan analisis regresi dilakukan baik untuk model 1 maupun model 2. 
HASIL PENELITIAN

Responden relatif berimbang antara pria (42.16\%) dan wanita (57.84\%). Sebagian besar responden Oppo didominasi oleh pengguna berusia 21-25 tahun sebesar $58,8 \%$ dan sisanya terbagi pada usia $<20$ tahun sebanyak 24 orang $(23,5 \%)$, persentase usia 26-30 tahun sebanyak 14 orang (13,7\%), dan persetase usia $>30$ tahun sebanyak 4 orang $(3,9 \%)$. Pekerjaan responden di dominasi oleh pekerjaan sebagai karyawan swasta sebanyak 52 orang (51\%) dan sisanya sebagai pelajar, PNS, dan seorang wirausahawan.

Penelitian menggunakan instrumen kuesioner sehingga dilakukan uji instrumen yaitu validitas dan reliabilitas. Variabel Word of Mouth terdiri dari 8 (delapan) item kuesioner yang seluruhnya valid dan reliabel. Variabel Citra Merek dilakukan terhadap 7 item pernyataan kuesioner yang seluruhnya valid dan reliabel. Variabel Kepercayaan Merek dilakukan terhadap 9 item pernyataan kuesioner yang seluruhnya valid dan reliabel. Loyalitas Pelanggan dilakukan terhadap 9 item pernyataan kuesioner yang seluruhnya valid dan reliabel. Data uji reliabilitas dapat dilihat pada tabel 2 .

Tabel 2. Uji Reliabilitas

\begin{tabular}{cccc}
\hline Var. & Item & $\begin{array}{c}\text { Cronbch } \\
\text { Alpha }\end{array}$ & Kesimpulan \\
\hline WOM & 8 & 0,914 & Reliabel \\
CM & 7 & 0,888 & Reliabel \\
KM & 9 & 0,915 & Reliabel \\
LP & 9 & 0,788 & Reliabel
\end{tabular}

Sumber: Data diolah, 2019
Tabel 3. Statistik Deskriptif

\begin{tabular}{|c|c|c|c|c|}
\hline Var. & Min. & Max. & Mean & Kategori \\
\hline WOM & 2,880 & 5,000 & 4,098 & Tinggi \\
\hline $\mathrm{CM}$ & 2,000 & 5,000 & 4,242 & $\begin{array}{l}\text { Sangat } \\
\text { Tinggi }\end{array}$ \\
\hline KM & 2,780 & 5,000 & 3,930 & Tinggi \\
\hline LP & 2,000 & 5,000 & 3,777 & Tinggi \\
\hline
\end{tabular}

Sumber: Data diolah, 2019

Tabel 3 memperlihatkan bahwa setiap variabel penelitian cenderung baik. Word of Mouth, Kepercayaan Merek dan Loyalitas tinggi sedangkan citra merek sangat tinggi.

Persyaratan analisis regresi linier ganda telah terpenuhi. Uji normalitas terpenuhi karena menghasilkan nilai Kolmogorov-smirnov $=0,060$ dengan probability Asymp. Sig. $=0,200$ dan uji multikolinieritas terpenuhi dengan diperolehnya nilai VIF kurang dari 2 untuk setiap variabel independen. Pada uji Heteroskedastisitas terpenuhi dengan diperolehnya nilai signifikansi (sig.) untuk variabel Word of Mouth (X1) sebesar 0,413, variabel citra merek (X2) sebesar 0,572 dan untuk variabel kepercayaan merek $(Z)$ nilai signifikansi (sig.) sebesar 0,419. Nilai sig dari ketiga variabel diatas menyatakan sig. $>$ 0,05 yang berarti tidak terjadi heteroskedasitas.

Uji kelayakan model pada penelitian ini terdapat dua pengujian koefisien determinasi yaitu Uji Koefisien Determinasi (R2) pertama yang menunjukkan bahwa kontribusi pengaruh variabel Word of Mouth dan citra merek terhadap kepercayaan merek sebesar 74,5\% sementara sisanya $25,5 \%$ berasal dari kontribusi variabel lain yang tidak dimasukkan dalam penelitian sebagaimana terlihat pada tabel 4 . 
Tabel 4. Koefisien Determinasi Pertama

\begin{tabular}{lcc}
\hline \multirow{2}{*}{$\begin{array}{c}\text { Variabel } \\
\text { Independen }\end{array}$} & \multicolumn{2}{c}{$\begin{array}{c}\text { Dependen: Kepercayaan } \\
\text { Merek }\end{array}$} \\
\cline { 2 - 3 } & $\mathrm{R}^{2}$ & Adjusted R \\
\hline Word of Mouth, \\
$\begin{array}{c}\text { Citra Merek, } \\
\text { Kepercayaan } \\
\text { Merek }\end{array}$ & 0,745 & 0,726 \\
\hline Sumber: Data diolah, 2019 &
\end{tabular}

Sedangkan Uji Koefisien Determinasi (R2) kedua menunjukkan bahwa kontribusi pengaruh variabel Word of Mouth dan citra merek terhadap variable loyalitas pelanggan sebesar 76,9\% sementara sisanya $23,1 \%$ berasal dari kontribusi variabel lain yang tidak dimasukkan dalam penelitian sebagaimana terlihat pada tabel 5 .

Tabel 5. Koefisien Determinasi Kedua

\begin{tabular}{|c|c|c|}
\hline \multirow{2}{*}{$\begin{array}{c}\text { Variabel } \\
\text { Independen }\end{array}$} & \multicolumn{2}{|c|}{$\begin{array}{c}\text { Dependen: Kepercayaan } \\
\text { Merek } \\
\end{array}$} \\
\hline & $\mathrm{R}^{2}$ & Adjusted R² \\
\hline $\begin{array}{c}\text { Word of Mouth, } \\
\text { Citra Merek, } \\
\text { Loyalitas } \\
\text { Pelanggan } \\
\end{array}$ & 0,769 & 0,754 \\
\hline Sumber: Data dio & ah, 2019 & \\
\hline $\begin{array}{l}\text { Pengujian } \\
\text { berdasar koefis } \\
\text { kedua serta nila } \\
\text { terangkum pada }\end{array}$ & $\begin{array}{l}\text { hipotesis } \\
\text { regresi } \\
\text { robabilita } \\
\text { abel } 6 .\end{array}$ & $\begin{array}{l}\text { dilakukan } \\
\text { pertama dan } \\
\text { sebagaimana }\end{array}$ \\
\hline
\end{tabular}

Tabel 6. Hasil Uji Hipotesis

\begin{tabular}{clccc} 
Hipotesis & \multicolumn{1}{c}{ Uraian Hipotesis } & T Value & Beta & Kesimpulan \\
\hline H1 & $\begin{array}{l}\text { Word of Mouth berpengaruh } \\
\text { terhadap Kepercayaan Merek }\end{array}$ & 3,549 & 0,271 & Diterima \\
H2 & $\begin{array}{l}\text { Citra Merek berpengaruh } \\
\text { terhadap Kepercayaan Merek }\end{array}$ & 7,597 & 0,581 & Diterima \\
H3 & $\begin{array}{l}\text { Kepercayaan Merek } \\
\text { berpengaruh terhadap }\end{array}$ & 4,188 & 0,429 & Diterima \\
H4 & $\begin{array}{l}\text { Loyalitas Pelanggan } \\
\text { Word of Mouth berpengaruh } \\
\text { terhadap Loyalitas Pelanggan }\end{array}$ & 2,201 & 0,182 & Diterima \\
H5 & $\begin{array}{l}\text { Citra Merek berpengaruh } \\
\text { terhadap Loyalitas Pelanggan }\end{array}$ & 2,486 & 0,244 & Diterima
\end{tabular}

Sumber: Data diolah, 2019 


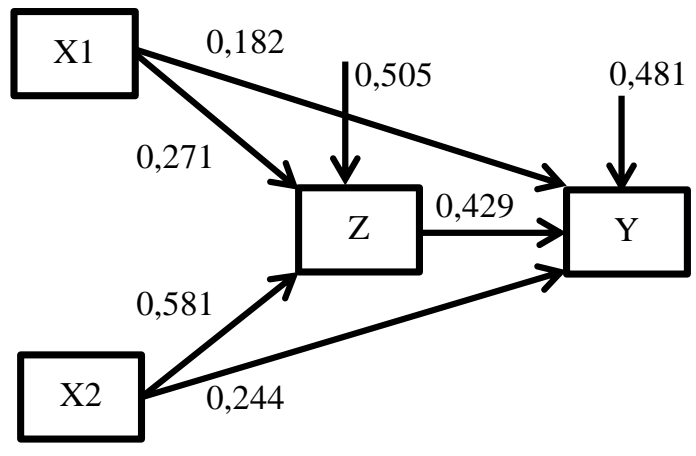

Gambar 3. Hasil Analisis Jalur

Tabel 7 memperlihatkan pengaruh variabel Word of Mouth (X1) terhadap loyalitas pelanggan (Y) adalah sebesar $29,83 \%$ dengan pengaruh langsung sebesar 18,2 \% dan pengaruh tidak langsung sebesar 11,63 \%. Pengaruh variabel citra merek (X2) terhadap loyalitas pelanggan (Y) adalah sebesar $49,32 \%$ dengan pengaruh langsung sebesar $24,4 \%$ dan pengaruh tidak langsung sebesar 24,92\%. Pengaruh variabel kepercayaan merek $(Z)$ terhadap loyalitas pelanggan $(Y)$ adalah sebesar 42,9 $\%$ dengan pengaruh langsung sebesar $37,3 \%$ dan pengaruh tidak langsung sebesar $20,7 \%$.

Tabel 7. Kausal Analisis Jalur

\begin{tabular}{ccc}
\hline \multirow{2}{*}{$\begin{array}{c}\text { Pengaruh } \\
\text { Variabel }\end{array}$} & \multicolumn{2}{c}{ Pengaruh Kausal } \\
\cline { 2 - 3 } & Langsung & $\begin{array}{c}\text { Tidak } \\
\text { Langsung }\end{array}$ \\
\hline $\mathrm{X}_{1}$ terhadap Y & 0,182 & $0,271 \times 0,429$ \\
Total & 0,182 & 0,1163 \\
\hline $\mathrm{X}_{2}$ terhadap Y & 0,244 & $0,581 \times 0.429$ \\
Total & 0,244 & 0,2492 \\
\hline Z terhadap Y & 0,429 & - \\
\hline
\end{tabular}

\section{PEMBAHASAN}

Penelitian menghasilkan model yang layak dimana hasil model penelitian pertama mampu menjelaskan 57,2\% variasi Kepercayaan Merek karena masukan faktor Word of Mouth dan Citra Merek. Sedangkan hasil model kedua mampu menjelaskan 56\% variasi Loyalitas Pelanggan karena masukan faktor Word of Mouth, Citra Merek, dan Kepecayaan Merek.

Penelitian menghasilkan temuan bahwa Word of Mouth dan Citra Merek memiliki pengaruh terhadap kepercayaan merek smartphone Oppo. Kepercayaan merek memiliki pengaruh terhadap loyalitas pelanggan dan Word of Mouth dan Citra Merek memiliki pengaruh positif terhadap loyalitas pelanggan smartphone Oppo.

\section{Pengaruh Word of Mouth terhadap Kepercayaan Merek}

Terdapat pengaruh positif Word of Mouth terhadap Kepercayaan Merek Smartphone Oppo. Rekomendasi mulut ke mulut (Word of Mouth) yang semakin baik akan mendatangkan kepercayaan.

Hasil ini sesuai dengan penelitian sebelumnya yang menekankan jika Word of Mouth berpengaruh konkret terhadap kepercayaan merek (Oktiani, et al., 2018; Hasan, 2013: 93). Penelitian ini juga mendukung sebagian besar temuan penelitian yang pernah ada (Hatta dan Setiarini, 2018; Yusfita dan Yulianto, 2018) dan menggugurkan temuan yang lain (Utami, 2019).

Intensitas dan kualitas word of mouth perlu ditingkatkan. Kadang orang tidak tertarik dengan iklan atau promosi atau bentuk komunikasi lainnya. Testimoni orang terdekat seringkali lebih dipercaya. Bisa jadi orang lebih tertarik terhadap suatu produk karena adanya testimoni dari orang-orang yang sebelumnya sudah menggunakan produk Smartphone Oppo memiliki kesan positif. 


\section{Pengaruh Citra Merek terhadap Kepercayaan Merek}

Terdapat pengaruh antara citra merek terhadap Kepercayaan Merek Smartphone Oppo dengan arah positif. Hal ini berarti bahwa semakin baik citra dimiliki sebuah merek maka kepercayaan terhadap merek tersebut akan semakin tinggi.

Penelitian ini berbeda dengan temuan yang menyatakan bahwa citra merek tidak berpengaruh terhadap loyalitas (Andjarwati dan Chusniartiningsih, 2019). Penelitian ini mendukung sebagian besar penyelitian yang menyebutkan bahwa terdapat pengaruh antara Citra Merek terhadap Kepercayaan Merek (Puspita, R., Yunus, M. dan Sulaiman, 2017).

Menjaga dan meningkatkan citra merek (brand image) merupakan aspek yang sangat penting. Upaya tersebut dapat dilakukan dengan membuat kesan yang baik, menarik perhatian dan menciptakan keunikan.

\section{Pengaruh Kepercayaan Merek terhadap Loyalitas Pelanggan}

Terdapat pengaruh antara Kepercayaan Merek terhadap Loyalitas Pelanggan Smartphone Oppo dengan arah positif. Semakin tinggi kepercayaan konsumen terhadap sebuah merek maka loyalitasnya akan semakin tinggi pula.

Kepercayaan merek sangat penting bagi pertukaran relasional dan menjadi dasar bagi terbentuknya hubungan yang strategis. Kepercayaan merek berpengaruh terhadap loyalitas pelanggan dengan mengekplorasi deteminasi loyalitas pelanggan (Eunil Park, 2017).

Tanpa adanya kepercayaan suatu hubungan tidak akan dapat berjalan dalam jangka waktu yang panjang. Oleh karena itu perlu pemilik produk menjaga integritas, dapat diandalkan, tidak mengecewakan konsumennya.
Pengaruh Word of Mouth terhadap Loyalitas Pelanggan

Terdapat pengaruh antara Word of Mouth terhadap Loyalitas Pelanggan Smartphone Oppo. Informasi dari pembicaraan, rekomendasi dan dorongan pengguna Oppo akan dapat meningkatkan kesetiaan pengguna terhadap merek Oppo. Penelitian ini sejalan dengan temuan penelitian sebelumnya dimana Word of Mouth berpengaruh terhadap loyalitas pelanggan (Hatta, 2018; Oliviana, 2017).

Penelitian ini juga menghasilkan temuan bahwa word of mouth mempengaruhi loyalitas secara tidak langsung yaitu kepercayaan. Jika word of mouth tinggi maka kepercayaan tinggi yang pada akhirnya akan meningkatkan loyalitas. Hal ini sejalan dengan penelitian sebelumnya (Oktiani dan Khadafi, 2018; Lock, 2016) yang menyatakan bahwa Word of Mouth berpengaruh terhadap kepercayaan merek dan berdampak pada loyalitas pelanggan.

\section{Pengaruh Citra Merek terhadap Loyalitas Pelanggan}

Terdapat pengaruh antara Citra Merek terhadap Loyalitas Pelanggan Smartphone Oppo dengan arah positif. Semakin baik citra merek Oppo maka pelanggan Oppo akan lebih setia.

Penelitian ini sejalan dengan penelitian sebelumnya (Umar, 2018) yang menekankan jika citra merek berpengaruh terhadap loyalitas pelanggan meskipun berlawanan dengan temuan penelitian lainyang menyatakan bahwa citra merek tidak berpengaruh terhadap loyalitas (Andjarwati dan Chusniartiningsih, 2019). Bagaimanapun loyalitas pelanggan dapat dibangun melalui peningkatan citra merek yang antara lain melalui kesan yang baik, produk dapat menarik, dan memiliki keunikan. Hal ini diperkuat hasil studi 
penelitian sebelumnya yang lainnya (Tamon, Mandey dan Wenas, 2019) yang menunjukkan citra merek memiliki pengaruh terhadap loyalitas pelanggan.

Penelitian ini juga menghasilkan temuan bahwa citra merek berpengaruh terhadap loyalitas melalui kepercayaan. Citra yang baik yang dimiliki Oppo dapat menambah kepercayaan merek pelanggan yang pada akhirnya meningkatkan loyalitas pelanggan. Hasil ini sejalan dengan penelitian sebelumnya (Mabkhot, 2017) yang mengatakan terdapat pengaruh antara citra merek terhadap loyalitas pelanggan dimediasi oleh kepercayaan merek.

\section{KESIMPULAN}

Penelitian menghasilkan temuan bahwa terdapat pengaruh Word of Mouth dan Citra Merek terhadap Kepercayaan Merek smartphone Oppo di Karawang dan terdapat pengaruh Word of Mouth, Citra Merek dan Kepercayaan Merek terhadap Loyalitas Pelanggan smartphone Oppo di Karawang. Word of Mouth dan citra merek berpengaruh terhadap loyalitas pelanggan Oppo melalui kepercayaan merek.

Pihak Manajemen Oppo Indonesia disarankan harus lebih memperhatikan aspek Word of Mouth, citra merek dan kepercayaan merek untuk mempertahankan kesetiaan konsumen. Perusahaan membuat strategi pemasaran yang berfokus terhadap kepercayaan merek sehingga konsumen semakin loyal terhadap merek. Kepercayaan itu sendiri bisa dibangun dengan memberi kesan yang baik dan meningkatkan citra.

\section{PUSTAKA}

Hasan, A. (2013). Marketing. Yogyakarta: Media Utama.

Mulyanto, H. dan Wulandari, A., (2010), Penelitian Metode dan Anlisis. Semarang : cv Agung

Richard, Chinomona, 2016, "Brand communication, brand image and brand trust as antecedents of brand loyalty in Gauteng Province of South Africa", African Journal of Economic and Management Studies Vol. 7 No. 1, 2016 pp. 124- 139

Shimp, T. A., 2014. Komunikasi Pemasaran Terpadu dalam Periklanan dan Promosi. Jakarta: Salemba Emapat.

Oktiani, A. dan Khadafi, R., 2018, “Pengaruh Brand Awareness dan Brand Image Serta Word of Mouth Terhadap Brand Trust dan Pembentukan Brand Loyality Pada Pelanggan C'Bezt Fried Chiken kecamatan Genteng Banyuwangi"; Jurnal COSTING Volume 1 Nomor 2, Juni 2018

Utami, Z.R., 2019, “Pengaruh Citra Merek Terhadap Loyalitas Pelanggan Yang Dimediasi Oleh Kepercayaan Merek Pada konsumen Maskara orifkame Surabaya", Jurnal STIE Pebarnas.

Puspita, R., Yunus, M. dan Sulaiman, 2017, “Pengaruh Faktor Sosial, Citra Merek, dan Kualitas Produk terhadap Kepercayaan Merek Serta Dampaknya Pada Loyalitas pelanggan Telepon Seluler", Jurnal Magister Manajemen Fakultas Ekonomi dan Bisnis Unsyiah Volume 1, No. 1, September 2017: 46

Agustina, N., Fauzi, A.D.H. dan Nuralam, I.P., 2018, "Pengaruh Kepuasan Pelanggan, biaya Beralih, dan kepercayaan Merek Terhadap Loyalitas pelanggan” Jurnal JAB Vol. 64 No. 1 
Alfian Surya Putra, A.S., 2018, "The Influence of Brand Image and Bran Trust on Customer Loyality (A Case Study on The Consumer of Oppo Smartphone in DIY)", Jurnal Manajemen Bisnis Indonesia Edisi 3

Husain, H. dan Hartati M, 2017, “Pengaruh Kepercayaan Merek Terhadap loyalitas Konsumen Pada Pengguna air Minum Kemasan Arindo Kota Kendari", Jurnal JMA Volume 6, Nomor 2

Oliviana, M, Mananeke, L. dan Mintardjo, C., 2017, "Pengaruh Brand Image dan Word of Mouth terhadap Loyalitas Konsumen pada RM Dahsyat" Jurnal EMBA Vol. 5 No. 2 Juni 2017: 1081 - 1092

Yusfita, N. dan Yulianto, E., 2018, "Pengaruh Experiental Marketing dan Word of Mouth Terhadap Loyalitas Pelnggan", JAB, Vol. 57 No. 1 April 2018

Hatta, I.H. dan Setiarini, "Pengaruh Word Of Mouth dan Switching Cost Terhadap Loyalitas Pelanggan dan Loyalitas", Jurnal Ilmiah Manajemen dan Bisnis, Vol. 19 No. 1, 2018: 32-40

Tamon, G.J., Mandey, S.L. dan Wenas, R.S., 2019, "Strategi Promosi, Citra Merek terhadap Loyalitas pelanggan Handphone Toyota (Studi pada Konsumen Handphone Toyota di Manado)", Jurnal EMBA Vol.7 No.1 Januari 2019: 701 - 710

Choiriah, E.N. dan Liana, L., 2019, "Pengaruh Kualitas Produk, Citra Merek, dan Kualitas Layanan TerhadapLoyalitas Pelanggan dimediasi Kepuasan Pelanggan (Studi pada Pelanggan Sepeda Motor Honda di Kota Semarang)", Jurnal MADIC ISSN: 2443-2601.

Andjarwati, A.L. dan Chusniartiningsih, E., 2019, "Pengaruh Kesadaran Merek dan Citra Merek terhadap Loyalitas Pelanggan Teh Pucuk Harum Wilayayah Surabaya Utara", Jurnal MINDS Vol. 5, No. 2 (Juli-Desember) 2018: 189-202

Lock, A.C., "Impact Of Brand Knowledge On Brand Trust in Private Higher Education Intitutions : How Do Word of Mouth Sources Intervene?", SARJANA Volume 31, No. 2, 2016: 13-32.

Eunil Park, E., Kim, K.J. dan Kwon, S.J., 2017, “Corporate social responsibility as a determinant of consumer loyalty: An examination of ethical standard, satisfaction, and trust", Journal of Business Research 76 (2017) 8-13.

Umar, H., 2018, “The Influence Of satisfaction and Brand Image On Consumer Loyality: Study On Cinema Industry In Jakarta Province, Indonesia", International Journal of Advanced Scientific Research \& Development Vol. 05, Iss. 01, Ver. I, Jan’ 2018: 01 - 12. 